\title{
Evaluation of cotton germplasm for morphological and biochemical host plant resistance traits against sucking insect pests complex
}

\author{
RIZWAN Muhammad ${ }^{1 *}$ (D), ABRO Saifullah', ASIF Muhammad Usman ${ }^{1}$, HAMEED Amjad $^{2}$, MAHBOOB Wajid $^{1,3}$, \\ DEHO Zaheer Ahmed ${ }^{1}$ and SIAL Mahboob Ali ${ }^{1}$
}

\begin{abstract}
Background: Sucking insect pests cause severe damage to cotton crop production. The development of insect resistant cotton cultivars is one of the most effective measures in curtailing the yield losses. Considering the role of morphological and biochemical host plant resistance (HPR) traits in plant defense, 12 cotton genotypes/varieties were evaluated for leaf area, leaf glanding, total soluble sugars, total soluble proteins, total phenolics, tannin and total flavonoids against fluctuating populations of whitefly, thrips and jassid under field conditions.

Results: The population of these insects fluctuated during the growing season and remained above threshold level (whitefly $>5$, thrips $>(8-10)$, or jassid $>1$ per leaf) during late June and early July. Strong and negative association of whitefly $(r=-0.825)$ and jassid $(r=-0.929)$ with seed cotton yield was observed. Mean population of insects were the highest in Glandless-1 followed by NIA-82 and NIA-M30. NIAB-Kiran followed by NIAB-878 and Sadori were the most resistant, with the mean population of 1.41, 1.60, 1.66 (whitefly); 2.24, 2.32, 2.53 (thrips) and 0.37, 0.31, 0.36 (jassid), respectively. The resistant variety NIAB-Kiran showed less soluble sugars $\left(8.54 \mathrm{mg} \cdot \mathrm{g}^{-1}\right)$, soluble proteins $\left(27.11 \mathrm{mg} \cdot \mathrm{g}^{-1}\right.$ ) and more phenolic (36.56 mg. $\mathrm{g}^{-1}$ ) and flavonoids $\left(13.10 \mathrm{mg} \cdot \mathrm{g}^{-1}\right)$ as compared with the susceptible check Glandless-1. Moreover, all insect populations were positively correlated with total soluble sugars and proteins. Whitefly populations exhibited negative response to leaf gossypol glands, total phenolics, tannins and flavonoids. The thrips and jassid populations had a significant and negative correlation with these four biochemical HPR traits.
\end{abstract}

Conclusion: The identified resistant resources and HPR traits can be deployed against sucking insect pests' complex in future breeding programs of developing insect resistant cotton varieties.

Keywords: Gossypium, Insect resistance, Plant defense, Plant breeding, Resistant traits, Sucking insects

\section{Introduction}

Cotton (Gossypium hirsutum L.) as a major crop has a $1.0 \%$ share in GDP and $5.5 \%$ in agriculture value addition in Pakistan. During 2017-2018, the cotton crop in Pakistan was cultivated on 2.699 Mha. The production stood at 11.935 million bales (One bale $=170 \mathrm{~kg}$ ),

\footnotetext{
* Correspondence: rzi_rizwan@yahoo.com

${ }^{1}$ Nuclear Institute of Agriculture (NIA), Tandojam, Sindh 70060, Pakistan

Full list of author information is available at the end of the article
}

which is $15 \%$ off the target of 14.04 million bales (Government of Pakistan 2017-2018). A decline in production has several reasons in which the sucking insect pests played a major role. Sucking insect/pest complex especially whitefly, jassid and thrips have caused severe damages to genetically-modified cotton systems in Pakistan. Notable yield losses have occurred in previous years (Razaq et al. 2013) and are expected in the future due to lack of resistant cultivars, increased insect pressure and pesticide resistance (Amjad and Aheer 2007).

(c) The Author(s). 2021 Open Access This article is licensed under a Creative Commons Attribution 4.0 International License, which permits use, sharing, adaptation, distribution and reproduction in any medium or format, as long as you give appropriate credit to the original author(s) and the source, provide a link to the Creative Commons licence, and indicate if changes were made. The images or other third party material in this article are included in the article's Creative Commons licence, unless indicated otherwise in a credit line to the material. If material is not included in the article's Creative Commons licence and your intended use is not permitted by statutory regulation or exceeds the permitted use, you will need to obtain permission directly from the copyright holder. To view a copy of this licence, visit http://creativecommons.org/licenses/by/4.0/ 
Genetic modification (GM) permitted the incorporation of toxins from bacteria (Bacillus thuringenesis, Bt) into cotton to control key Lepidopteron pests. However, sucking insect pest complex (whitefly, jassid and thrips) which is not controlled by Bt cotton has emerged as a new problem. This sucking complex causes significant loss in yield and fiber quality, and their management is also a key challenge for cotton growers. Losses up to $40 \%$ are reported due to sucking complex (Oerke 2006; Aslam et al. 2004; Nizamani et al. 2002). Significant losses $>12 \%$ were estimated even after taking control measures (Oerke 2006). Current control measures include the use of different chemicals as pesticides which is associated with high cost, pesticide resistance and environmental risks (Costa et al. 2003). Alternative methods should be opted for the control of these sucking insects. Host plant resistance (HPR) offers an opportunity for effective control of sucking insect pests as an economically and environmentally safe strategy in the GM cotton system (Khan et al. 2003). Khalil et al. (2017) studied the role of some morphological plant traits against sucking insect pest complex in six genotypes of cotton. They identified the negative response of whitefly to gossypol glands on leaf lamina, midrib and vein. Aslam and Saeed (2004) studied the comparative performance of 22 cotton genotypes against sucking complex. They investigated the relationship between leaf morphological traits and the population of sucking insects. Perveen et al. (2001) investigated the biochemical HPR basis of insect resistance in cotton, and found that the resistant varieties showed more phenolics and tannin as compared with the susceptible varieties; the negative correlations were witnessed between total phenols and the insect attack.

Therefore, the deployment of morphological and biochemical HPR traits as a cotton plant defense mechanism provides an alternative management strategy and controls these insect pests. Cotton cultivars having HPR against these insects would entail fewer pesticide applications, reducing costs and risks associated with pesticide resistance and beneficial the insect populations. Previously, researchers have focused on morphological HPR traits with only one or two reports on biochemical HPR (phenolics and tannins) in cotton. Compared with these studies, we used a much broader range of germplasm covering the morphobiochemical HPR traits from toxic to attractive to insects, such as higher contents of soluble proteins and sugars. Further, genotypes used in our study are also advanced and new genetic resources. Therefore, keeping in view the above facts, the present study investigates the response of some advanced lines and cultivars against sucking insect pest complex and identifies the morpho-biochemical basis of insect resistance by exploiting host plant resistance traits.

\section{Materials and methods}

\section{Study site and experimental materials}

The research work was conducted at Plant Breeding and Genetics Division, Nuclear Institute of Agriculture (NIA), Tando Jam, Pakistan during the Kharif season, 2018-2019. The experimental material consisted of 12 diverse cotton advanced lines and cultivars (NIAB-878, NIA-M30, NIA-H24, NIA-HM48, NIA-Bt.30, NIA-H32, NIA-H67, NIAB-112, Sadori, NIAB-Kiran, and NIA-82) including one glandless genotype (Glandless-1) as the susceptible check.

\section{Evaluation of cotton genotypes against sucking insects under field conditions \\ Field experiment design}

The experimental materials were sown in Randomized Complete Block Design (RCBD) blocks during May, 2018. The plot size was $6.1 \mathrm{~m} \times 3.0 \mathrm{~m}$ with four rows. Plant $\times$ plant and row $\times$ row distance was $30 \mathrm{~cm}$ and 75 $\mathrm{cm}$, respectively. Three replicates, each of 12 genotypes, produced a total of 36 plots. Each plot comprised four rows of 20 cotton plants for a total of 80 plants. Standard agronomic practices were performed throughout the growing season. Plant protection measures were not adopted in order to expose the genotypes to insect attack. The experimental materials were harvested during October, 2018.

\section{Estimation of sucking insect pest infestation}

The population of adults per leaf of cotton whitefly (Bemesia tabaci), thrips (Thrips tabaci) and jassid (Amrasca devastans) were recorded at weekly intervals, early in the morning, from 20 days after sowing up to the picking of seed cotton. Five plants were tagged randomly in each replication of the treatment. From each plant, data were recorded from three leaves, one from the upper leaf, one from the middle and one from the lower portion of the plant and then converted into per leaf basis (Ahmad et al. 2011). A hand magnifying lens was used for counting the sucking insect population. A total of 11 observations were recorded for about 3 months during the study.

\section{Estimation of morphological and biochemical HPR traits}

Leaf area and glanding The above randomly selected five plants were also used to measure morphological HPR traits (leaf area and leaf glanding). Five leaves per plant from different positions (upper, middle and lower) of each plant were cut, bagged, and carried to the laboratory. The leaf area $\left(\mathrm{cm}^{2}\right)$ of 25 randomly selected leaves was measured with a leaf area meter and means were computed. The leaf glanding was also estimated from 
the lower side of these leaves and scored by using the following scale given by Romano and Scheffler (2008).

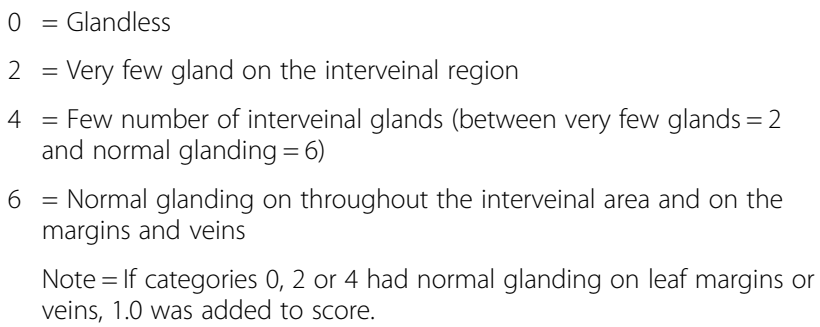

Total soluble sugars (TSS)The amount of TSS $\left(\mathrm{mg}^{-\mathrm{g}^{-1}}\right)$ in fully expanded youngest leaves randomly collected from different plants of each genotype was estimated by phenol sulphuric acid reagent method given by Dubois et al. (1951). Leaf samples $(0.05 \mathrm{~g})$ were extracted in $95 \%$ methanol solution $(2 \mathrm{~mL})$ for $48 \mathrm{~h}$ at room temperature. Assay solution was prepared by using $96 \%$ sulphuric acid, 5\% phenol and sample extract. A $1 \mathrm{~mL}$ of leaf extract, $0.5 \mathrm{~mL}$ phenol solution, and $2.5 \mathrm{~mL}$ sulphuric acid were added in glass tubes. Each tube was gently agitated during acid addition and then kept in a water bath at $26-30^{\circ} \mathrm{C}$ for $20 \mathrm{~min}$. Then absorbance of the colored solution was measured at $490 \mathrm{~nm}$ using spectrophotometer VIS-1100 (BMS, Canada). Different concentrations $(0.1-3 \mathrm{mg}$ with $0.5 \mathrm{mg}$ interval and 3-6 $\mathrm{mg}$ with $1 \mathrm{mg}$ interval) of glucose were prepared in $4 \mathrm{~mL}$ distilled water. After mixing the standards and placing them in the water bath at $26-30^{\circ} \mathrm{C}$ for $20 \mathrm{~min}$, absorbance was measured at $490 \mathrm{~nm}$. A standard curve was drawn by plotting glucose concentration on the $x$-axis against their absorbance at $490 \mathrm{~nm}$ on the $y$-axis.

Total soluble proteins (TSP) The TSP was measured using Bradford protein estimation assay (Bradford 1976). Briefly, $0.5 \mathrm{~g}$ fully expanded youngest leaves randomly collected from different plants were ground and homogenized in $10 \mathrm{~mL}$ of ice-cold potassium phosphate buffer. Then samples were centrifuged for $100 \mathrm{~min}$ at $15000 \times g$. The supernatant $(5 \mu \mathrm{L})$ was then mixed with a $1 \mathrm{~mL}$ reaction solution containing Coomassie Brilliant Blue G-250 $(0.02 \mathrm{~g})$, which was dissolved in $10 \mathrm{~mL}$ of $95 \%$ ethanol. To this solution, $20 \mathrm{~mL}$ of $85 \%$ phosphoric acid was added. The resulting solution was diluted to a final volume of $200 \mathrm{~mL}$, and bovine serum albumin was used as a standard.

Total phenolics (TP) The TP was measured using the Folin-Ciocalteu reagent following a method adapted from Singleton and Rossi (1965). The fully expanded youngest leaves of $0.05 \mathrm{~g}$ randomly collected from different plants were extracted in a $95 \%$ methanol solution
$(500 \mu \mathrm{L})$ for $48 \mathrm{~h}$ at room temperature. The extract was centrifuged at $14000 \mathrm{rmin}^{-1}$ for $10 \mathrm{~min}$. The supernatant $(100 \mu \mathrm{L})$ was added to a $100 \mu \mathrm{L}$ of $10 \%$ FolinCiocalteu reagent, after $2 \mathrm{~min}, 800 \mu \mathrm{L}$ of $7.5 \% \mathrm{Na}_{2} \mathrm{CO}_{3}$ solution was added. After shaking, the solutions were maintained at room temperature for $1 \mathrm{~h}$. Absorption was measured at $765 \mathrm{~nm}$ using the spectrophotometer VIS1100. Gallic acid standard solutions were used to calibrate the method and the results were expressed as gallic acid equivalents in milligram per gram in fresh weight.

Tannins Fresh leaf samples $(0.05 \mathrm{~g})$ were extracted in a $95 \%$ methanol solution $(500 \mu \mathrm{L})$ for $48 \mathrm{~h}$ at room temperature with occasional stirring. The extract was centrifuged at $14000 \mathrm{rmin}^{-1}$ for $10 \mathrm{~min}$. The supernatant was used to estimate tannins following the method described by Burns (1971). Tannin in the sample was measured at $765 \mathrm{~nm}$ using tannic acid as standard. The total tannins were expressed as milligram per gram fresh weight.

Total flavonoids (TF) The TF were determined following the method described by Chang et al. (2002). The fully expanded youngest leaves of $0.05 \mathrm{~g}$ randomly collected from different plants were extracted in a $95 \%$ methanol solution $(500 \mu \mathrm{L})$ for $48 \mathrm{~h}$ at room temperature. The TF assay was performed using an extract $(200 \mu \mathrm{L})$ dissolved in $800 \mu \mathrm{L}$ distilled water, $10 \%$ aluminium chloride $(50 \mu \mathrm{L}), 1 \mathrm{~mol} \cdot \mathrm{L}^{-1}$ potassium acetate $(50 \mu \mathrm{L})$, and $1.4 \mathrm{~mL}$ distilled water. After shaking, the mixtures were incubated at room temperature for $40 \mathrm{~min}$ and the absorbance was then measured at 415 $\mathrm{nm}$ using the spectrophotometer VIS-1100. The TFs were expressed as rutin equivalents in milligram per gram in fresh weight.

\section{Statistical analysis}

The data collected were analyzed separately for each parameter and subjected to analysis of variance following Steel et al. (1997). The means were compared using least significant differences (LSD) test (alpha = 0.05). Correlation matrix was computed using XLSTAT 2012. The values presented are mean of three replicates \pm standard error (SE), respectively.

\section{Results}

Population dynamics of sucking insect pests

The population of sucking insect pests (average of the 12 genotypes) fluctuated throughout the cotton crop growth season during 2018/2019 (Fig. 1). Whitefly infestation increased from the 3rd week of June and exceeded the threshold level and reached up to 10 whiteflies per leaf during the 4th week of June and the 3rd week of July. Thrips infestation also exceeded the 


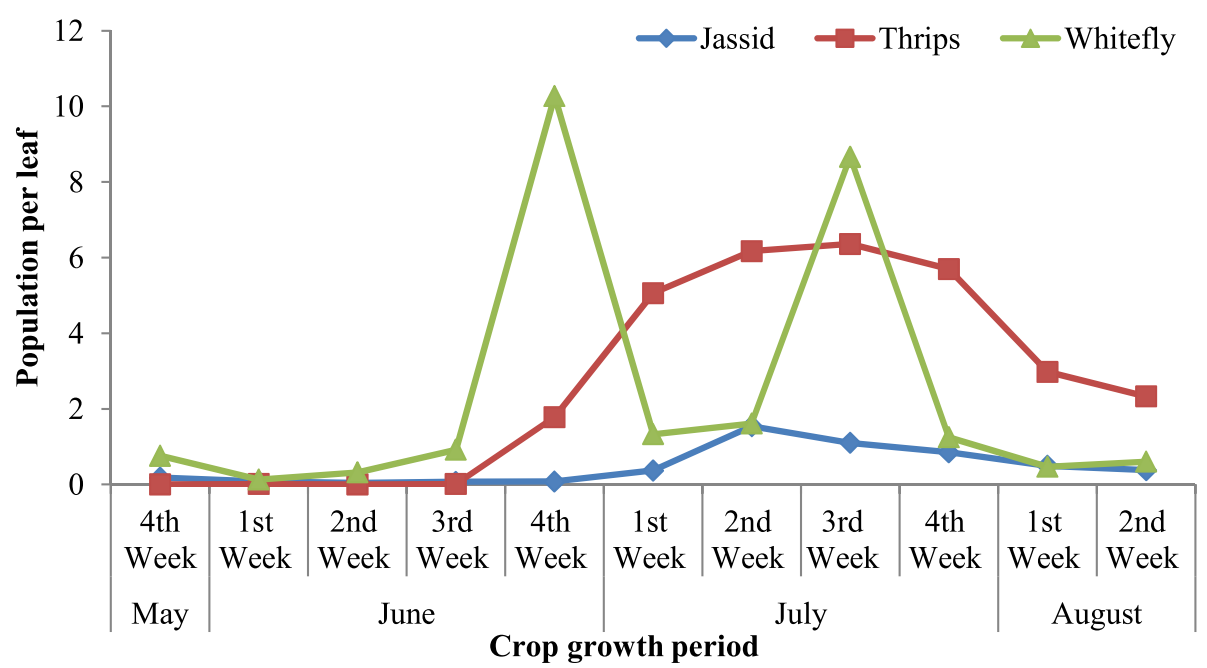

Fig. 1 Fluctuation in sucking insect pest complex population (data from the average of 12 cotton genotypes) during the growing season 2018/2019

threshold level ( $>6$ thrips per leaf) from the 2nd to 4th week of July. A similar trend was also observed for jassid infestation. The jassid population increased from the 1st week of July ( $>1$ jassid per leaf) till the 4th week of July. The months of June and July were the most favorable for sucking insect pest infestation as their peak abundance was recorded in these months.

\section{Impact of cotton genotypes on sucking insect pests}

Significant differences among genotypes were observed for sucking insects per leaf (Table 1). The cultivars, NIABKiran followed by NIAB-878 and Sadori, showed less infestation of whitefly, i.e., 1.41, 1.60, and 1.66 per leaf, respectively. The genotype Glandless-1 was the most susceptible having a whitefly infestation of 4.95 per leaf. Next higher numbers of whitefly were observed on NIA-82 (4.07 per leaf) followed by NIA-M30 (2.89 per leaf). The genotypes Glandless- 1 and NIA-82 were also found susceptible to thrips, having 3.70 and 2.96 thrips per leaf, respectively. Thrips infestation was less in NIAB-Kiran (2.24 per leaf) followed by NIAB-112 (2.29 per leaf), NIAB878 (2.32 per leaf) and NIA-H32 (2.35 per leaf). Regarding jassid infestation, the cultivars NIAB-878 (0.31 per leaf) followed by Sadori ( 0.36 per leaf) and NIAB-Kiran ( 0.37 per leaf) were less attacked. Jassid infestation was higher in genotypes Glandless-1 (0.78 per leaf) followed by NIA-H24 (0.57 per leaf). Overall, NIAB-Kiran, NIAB-878 and Sadori were less attacked by sucking insect pest complex.

Table 1 Mean population of sucking insect pests (number/leaf) on different genotypes of cotton

\begin{tabular}{llll}
\hline Genotypes & \multicolumn{1}{c}{ Whitefly } & Thrips & Jassid \\
\hline NIAB-Kiran & $1.41 \pm 0.21 \mathrm{f}$ & $2.24 \pm 0.21 \mathrm{e}$ & $0.37 \pm 0.06 \mathrm{~cd}$ \\
NIAB-878 & $1.60 \pm 0.21 \mathrm{f}$ & $2.32 \pm 0.22 \mathrm{de}$ & $0.31 \pm 0.01 \mathrm{~d}$ \\
Sadori & $1.66 \pm 0.12 \mathrm{ef}$ & $2.53 \pm 0.08 \mathrm{bcde}$ & $0.36 \pm 0.05 \mathrm{~cd}$ \\
NIAB-112 & $1.96 \pm 0.12 \mathrm{def}$ & $0.48 \pm 0.04 \mathrm{bc}$ \\
NIA-H32 & $2.21 \pm 0.14 \mathrm{cdef}$ & $2.29 \pm 0.30 \mathrm{e}$ & $0.53 \pm 0.06 \mathrm{bc}$ \\
NIA-Bt.30 & $2.46 \pm 0.13 \mathrm{cde}$ & $2.35 \pm 0.30 \mathrm{de}$ & $0.43 \pm 0.04 \mathrm{bcd}$ \\
NIA-H67 & $2.50 \pm 0.42 \mathrm{~cd}$ & $2.69 \pm 0.23 \mathrm{bcde}$ & $0.56 \pm 0.08 \mathrm{~b}$ \\
NIA-HM48 & $2.58 \pm 0.10 \mathrm{~cd}$ & $3.03 \pm 0.07 \mathrm{~b}$ & $0.48 \pm 0.04 \mathrm{bc}$ \\
NIA-H24 & $2.72 \pm 0.57 \mathrm{~cd}$ & $2.98 \pm 0.13 \mathrm{bc}$ & $0.57 \pm 0.08 \mathrm{~b}$ \\
NIA-M30 & $2.89 \pm 0.19 \mathrm{c}$ & $2.40 \pm 0.17 \mathrm{cde}$ & $0.56 \pm 0.06 \mathrm{~b}$ \\
NIA-82 & $4.07 \pm 0.40 \mathrm{~b}$ & $2.89 \pm 0.29 \mathrm{bcd}$ & $0.52 \pm 0.04 \mathrm{bc}$ \\
Glandless-1 (Susceptible Check) & $4.95 \pm 0.26 \mathrm{a}$ & $2.96 \pm 0.16 \mathrm{bc}$ & $0.78 \pm 0.08 \mathrm{a}$ \\
\hline
\end{tabular}

These are the means of the season in which population of the sucking insect pests were recorded

Means sharing similar letters in columns are not significantly different by LSD test at the 0.05 probability level $(P>0.05)$ 


\section{Morpho-biochemical HPR traits in different genotypes of cotton}

Highly significant differences among cotton genotypes were observed for the studied traits including leaf area, leaf glanding, total soluble sugars and proteins content, total flavonoids content, total phenols content, and seed cotton yield except tannins content, which does not differ significantly in most materials (Table 2). Leaf area of studied genotypes ranged from $88.68 \mathrm{~cm}^{2}$ for NIAM30 to $55.88 \mathrm{~cm}^{2}$ for NIA-82. NIAB-112 possessed higher leaf gossypol glanding (5.00) followed by NIAB878 (4.87), NIA-H24 (4.80) and NIAB-Kiran (4.67). Glandless-1 genotype showed very few leaf gossypol glands (0.67). However, the Glandless-1 (the susceptible check) showed higher total soluble sugars content, i.e., $22.67 \mathrm{mg} \cdot \mathrm{g}^{-1}$, followed by NIA-82 (17.38 $\left.\mathrm{mg} \cdot \mathrm{g}^{-1}\right)$, NIAH24 (15.27 $\left.\mathrm{mg}^{-\mathrm{g}^{-1}}\right)$, NIAB-112 (15.07 $\left.\mathrm{mg} \cdot \mathrm{g}^{-1}\right)$, NIA-

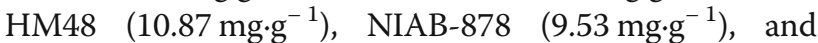
NIAB-Kiran $\left(8.54 \mathrm{mg}^{-1} \mathrm{~g}^{-1}\right.$ ). Total soluble proteins content was ranked in decreasing order as NIA-82 (57.09 $\mathrm{mg} \cdot \mathrm{g}^{-1}$ ) followed by Glandless-1 (55.55 $\left.\mathrm{mg} \cdot \mathrm{g}^{-1}\right)$, NIAM30 (48.11 mg.g $\left.{ }^{-1}\right)$, NIAB-878 (30.22 mg.g $\left.{ }^{-1}\right)$, and NIAB-Kiran (27.11 mg.g $\left.{ }^{-1}\right)$. NIAB-Kiran showed higher total phenols content $\left(36.56 \mathrm{mg} \cdot \mathrm{g}^{-1}\right)$ and tannins content $\left(3.30 \mathrm{mg} \cdot \mathrm{g}^{-1}\right)$. Next to NIAB-Kiran, NIAB-878 showed $34.58 \mathrm{mg} \cdot \mathrm{g}^{-1}$ of total phenols content and $3.13 \mathrm{mg} \cdot \mathrm{g}^{-1}$ of tannins content. Total flavonoids content of NIAB-Kiran $\left(13.10 \mathrm{mg} \cdot \mathrm{g}^{-1}\right)$, NIAB-878 (11.21 $\left.\mathrm{mg} \cdot \mathrm{g}^{-1}\right)$, and Sadori $\left(9.80 \mathrm{mg}^{-1}\right)$ were higher than that of the susceptible check Glandless-1. Overall, considerable variations existed among genotypes for studied HPR traits.

\section{Correlation between morpho-biochemical HPR traits and the sucking insects population}

Correlations among studied HPR traits and sucking insect pests are presented in Table 3. Leaf gossypol glanding, total phenolics, tannins and total flavonoids had a significant and negative relation with the whitefly infestation, whereas total soluble sugar content and total soluble proteins content correlated positively with the whitefly population. There was no significant correlation between leaf area and the whitefly population. Similar trend for correlation of studied HPR traits with thrips and jassid infestation were observed.

\section{Effect of sucking insect pest's population on seed cotton yield of different cotton genotypes}

Sadori produced seed cotton yield of $2237 \mathrm{~kg} \cdot \mathrm{ha}^{-1}$ followed by NIAB-878 (2 $\left.209 \mathrm{~kg} \cdot \mathrm{ha}^{-1}\right)$, NIAB-Kiran (2 $186 \mathrm{~kg} \cdot \mathrm{ha}^{-1}$ ), and NIA-Bt. 30 (2 $129 \mathrm{~kg} \cdot \mathrm{ha}^{-1}$ ). The susceptible check, i.e., Glandless-1 produced seed cotton yield of $1011 \mathrm{~kg} \cdot \mathrm{ha}^{-1}$ (Table 2). As correlation of whitefly with seed cotton yield is concerned, it had strong and negative relation with seed cotton yield. Jassid infestation had a highly strong and negative association with seed cotton yield, too (Table 3). Overall, above threshold level of sucking insects significantly reduces seed cotton yield. Only genotypes, Sadori, NIAB-878, NIAB-Kiran, and NIA-Bt.30 showed less penalty on seed cotton yield under severe attack of sucking insects.

\section{Discussion}

The sucking insect pest population exceeded threshold level during June and July. This trend persisted from the last couple of years and expected to continue in the coming future. This is mainly due to the favorable weather conditions (high temperature and relative humidity) for sucking insects, lack of resistant cultivars and pesticide resistance (Amjad and Aheer 2007; Razaq et al. 2013; Nemade et al. 2018). In present study, two peaks of the whitefly population have been observed during the growing season. The possible reason for this fluctuation might be the change in weather condition. As whitefly is a highly movable insect, most influenced by rainfall, humidity and wind speed specifically in our field conditions (Tando Jam, Pakistan). Population fluctuation trend observed in present study is also in line with the results of Arshad and Anjum (2010) and Saleem et al. (2018) who observed sucking insects peak infestation in late July. In present investigation, 12 genotypes and cultivars including one susceptible check Glandless-1 were evaluated against sucking insects. Significant differences among genotypes were observed for sucking insects per leaf. The cultivars NIAB-Kiran, NIAB-878 and Sadori were less attacked by sucking insect pest complex. Several studies have been carried out to evaluate the response of cotton germplasm to sucking pest's resistance (Khalil et al. 2017; Pathan et al. 2007; Saleem et al. 2018). Aslam and Saeed (2004) evaluated 22 cotton genotypes for their comparative resistance to whitefly, jassid and thrips where the minimum mean population of whitefly was 0.5 per leaf on genotype $\mathrm{BH}$ 121 and CRIS-467, thrips 0.8 per leaf on CIM-499 and jassid 0.6 per leaf on MNH-635.

HPR investigation of resistant resources from present study has revealed the mechanism behind their resistance to sucking insect infestation. The sucking insects population negatively correlated with leaf gossypol glands, which is in agreement with the findings of Arif et al. (2006), Irfan et al. (2008) and Khalil et al. (2017) who observed leaf gossypol glands as a source of resistance against whitefly, thrips and jassid. This negative association indicates the presence of high gossypol content in gossypol glands present on the leaves of studied genotypes. However, the results of Khan et al. (2010) and Zia et al. (2011) were contradictory, as they observed positive response of whitefly with gossypol contents. This might be due to 


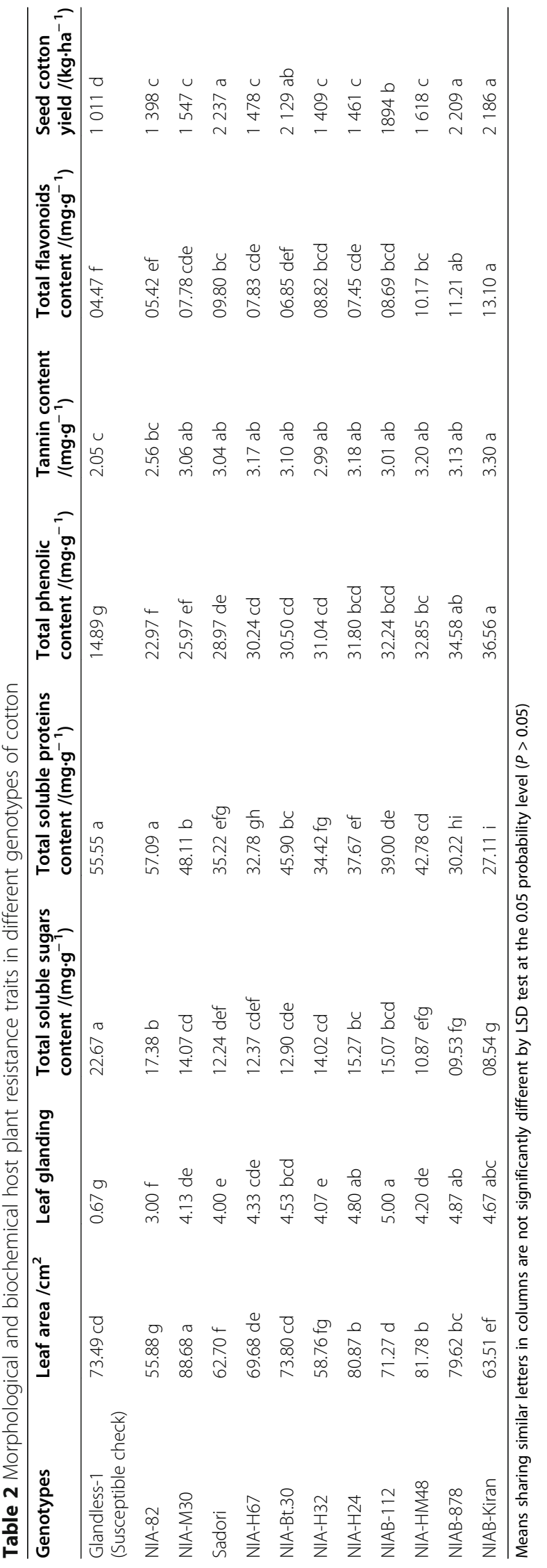


Table 3 Correlation coefficient values between sucking insect pests population (number/leaf) and morpho-biochemical host plant resistance traits across different cotton genotypes

\begin{tabular}{llll}
\hline Host plant resistance traits & Whitefly & Thrips & Jassid \\
\hline Leaf area $/ \mathrm{cm}^{2}$ & $0.020^{\mathrm{ns}}$ & $0.153^{\mathrm{ns}}$ & $0.132^{\mathrm{ns}}$ \\
Leaf glanding & $-0.865^{\mathrm{a}}$ & $-0.836^{\mathrm{a}}$ & $-0.730^{\mathrm{a}}$ \\
Total soluble sugars content $/\left(\mathrm{mg} \cdot \mathrm{g}^{-1}\right)$ & $0.887^{\mathrm{a}}$ & $0.661^{\mathrm{b}}$ & $0.856^{\mathrm{a}}$ \\
Total soluble proteins content $/\left(\mathrm{mg} \cdot \mathrm{g}^{-1}\right)$ & $0.883^{\mathrm{a}}$ & $0.729^{\mathrm{a}}$ & $0.622^{\mathrm{b}}$ \\
Total phenolic content $/\left(\mathrm{mg} \cdot \mathrm{g}^{-1}\right)$ & $-0.915^{\mathrm{a}}$ & $-0.838^{\mathrm{a}}$ & $-0.776^{\mathrm{a}}$ \\
Tannin content $/\left(\mathrm{mg} \cdot \mathrm{g}^{-1}\right)$ & $-0.870^{\mathrm{a}}$ & $-0.723^{\mathrm{a}}$ & $-0.701^{\mathrm{a}}$ \\
Total flavonoids content $/\left(\mathrm{mg} \cdot \mathrm{g}^{-1}\right)$ & $-0.870^{\mathrm{a}}$ & $-0.694^{\mathrm{b}}$ & $-0.773^{\mathrm{a}}$ \\
\multicolumn{1}{c}{ Seed cotton yield $/\left(\mathrm{kg} \cdot \mathrm{ha} \mathrm{C}^{-1}\right)$} & $-0.825^{\mathrm{a}}$ & $-0.684^{\mathrm{b}}$ & $-0.929^{\mathrm{a}}$ \\
\hline
\end{tabular}

ns Non-significant

${ }^{a}$ Correlation is significant at the 0.01 level

${ }^{\mathrm{b}}$ Correlation is significant at the 0.05 level

the presence of low gossypol content in the gossypol glands of the studied genotypes. Similarly, total phenolics and tannins content had negative correlation with sucking insect's infestation which is in confirmation with Butter et al. (1992) and Perveen et al. (2001) who advocated the role of phenolics content in cotton plant defense against different insects. They observed direct correlation between insect attack and total phenols and tannins content. Butter et al. (1992) identified that cultivars with greater total phenolic and tannin contents in leaves support fewer whitefly eggs. Dixit et al. (2017) reported that phenolics accumulation upon insect infestation varied in cotton genotypes. Phenols are kinds of plant secondary metabolites involved in plant defence against insects (War et al. 2012). They either directly affect insect growth and development or indirectly by acting as oviposition deterrents (Dixit et al. 2017). However, these results are in contradiction with Acharya and Singh (2008) who reported non-significant negative correlation of total phenol and tannin with the whitefly population. No specific reason was provided for this non-significant negative correlation, but one can infer that there may be some other defensive traits contributing in host plant resistance of these genotypes.

In our study, total flavonoids content also exhibited negative correlation with the sucking insect's population and this is in confirmation with the results of Butter et al. (1992) who observed negative correlation of total flavonoids content with the population density of whitefly. In present study, total soluble sugars and proteins content were positively correlated with the population densities of whitefly, thrips and jassid. Genotypes with high soluble sugars and proteins content were observed to be more susceptible to the sucking insect pests. These results are in confirmation with Athar et al. (2011) and Sonalkar (2020) who reported positive association of leaf soluble proteins and sugars content with whitefly infestation.
However, Butter et al. (1992) observed negative correlation between total sugars content and population density of whitefly. Involvement of total soluble sugars content, proteins content and some micronutrients in having more insects feeding on plants has been reported in different plant insect interaction studies (Athar et al. 2011; Sonalkar 2020). As for as yield is concerned, Sadori produced maximum seed cotton yield of $2237 \mathrm{~kg} \cdot \mathrm{ha}^{-1}$ followed by NIAB-878 (2 $\left.209 \mathrm{~kg} \cdot \mathrm{ha}^{-1}\right)$, NIAB-Kiran (2 $186 \mathrm{~kg} \cdot \mathrm{ha}^{-1}$ ) and NIA-Bt.30 (2 $\left.129 \mathrm{~kg} \cdot \mathrm{ha}^{-1}\right)$. Our results showed that, NIA-Bt.30 have higher yield but lower phenolics, tannins, flavonoids and higher soluble proteins content compared with NIA-HM48. This might be also due to high gossypol content because NIABt.30 leaves possess higher gossypol glanding and less insect infestation as compared with NIA-HM48.

\section{Conclusion}

Populations of the sucking insects, viz., whitefly, thrips and jassid are influenced by numerous biochemical constituents present in cotton genotypes, positively or negatively. Cotton varieties less attacked/preferred by these pests would help in pest management of cotton. It can be concluded that considerable variation exists among cotton genotypes having morpho-biochemical host plant resistance traits, which can be deployed for the breeding of sucking insect pest resistant cultivars.

\section{Authors' contributions \\ Rizwan M conceived the idea, recorded data in field and laboratory, prepared draft and finalized the manuscript. Abro S supervised the work, helped in the execution of field experiment. Asif MU recorded insect pest data and helped in data analysis. Hameed A helped in the estimation of biochemical parameters. Mahboob W helped in formulating methodology for estimation of biochemical parameters. Deho ZA helped in the execution of field experiment. Sial MA validated the idea and provided technical inputs in writing the manuscript and proof reading. The author(s) read and approved the final manuscript.}

Availability of data and materials

The data generated and materials used in this study are available from the corresponding author on reasonable request.

\section{Declarations}

Ethics approval and consent to participate

Not applicable.

Consent for publication

All co-author has consent for submission of manuscript.

\section{Competing interests}

The authors declare that there are no competing interests.

\section{Author details}

${ }^{1}$ Nuclear Institute of Agriculture (NIA), Tandojam, Sindh 70060, Pakistan.

${ }^{2}$ Nuclear Institute for Agriculture and Biology (NIAB), Faisalabad 38000,

Pakistan. ${ }^{3}$ College of Plant Science and Technology, Huazhong Agricultural University, Wuhan 430070, China. 
Received: 2 December 2020 Accepted: 27 May 2021

Published online: 01 July 2021

\section{References}

Acharya VS, Singh AP. Biochemical basis of resistance in cotton to the whitefly, Bemisia tabaci Genn. J Cotton Res Dev. 2008:22(2):195-9.

Ahmad N, Khan M, Tofique M, et al. Insect pests management of Bt cotton through the manipulation of different eco-friendly techniques. Nucleus. 2011; 48(3):249-54.

Amjad A, Aheer GM. Varietal resistance against sucking insect pests of cotton under Bahawalpur ecological conditions. J Agric Res. 2007;45:205-8.

Arif MJ, Gogi MD, Ahmad G. Role of morpho-physical plant factors imparting resistance in cotton against thrips, Thrips tabaci Lind. (Thripidae: Thysanoptera). Arab J PI Prot. 2006;24:57-60.

Arshad M, Anjum S. Studying the sucking insect pests community in transgenic Bt cotton. Intern J Agric Biol. 2010;12(5):764-8.

Aslam M, Razaq M, Shah SA, et al. Comparative efficacy of different insecticides against sucking pests of cotton. J Res Sci. 2004;15:53-8.

Aslam M, Saeed NA. Comparative resistance of different cotton genotypes against sucking insect pest complex of cotton. Sarhad J Agric. 2004;20(3): $441-5$

Athar $\mathrm{H}$, Bhatti AR, Bashir $\mathrm{N}$, et al. Modulating infestation rate of white fly (Bemicia tabaci) on okra (Hibiscus esculentus L.) by nitrogen application. Acta Physiol Plant. 2011;33:843-50. https://doi.org/10.1007/s11738-010-0609-4.

Bradford MM. A rapid and sensitive method for the quantitation of microgram quantities of protein utilizing the principle of protein-dye binding. Anal Biochem. 1976;72:248-54. https://doi.org/10.1006/abio.1976.9999.

Burns RE. Method for estimation of tannin in grain sorghum. Agron J. 1971;63(3): 511-2. https://doi.org/10.2134/agronj1971.00021962006300030050x.

Butter NS, Vir BK, Kaur G, et al. Biochemical basis of resistance to whitefly Bemisia tabaci Genn. (Aleyrodidae: Hemiptera) in cotton. Trop Agric. 1992;69(2):11922.

Chang CC, Yang $\mathrm{MH}$, Wen $\mathrm{HM}$, et al. Estimation of total flavonoid content in propolis by two complementary colorimetric methods. J Food Drug Anal. 2002;10(3):178-82. https://doi.org/10.38212/2224-6614.2748.

Costa DB, Souza B, Carvahlo GA, et al. Residual action of insecticides to larvae of Chrysoperla externa (Hagen, 1861) (Neuroptera: Chrysopidae) under greenhouse conditions. Cienc Agrotec Lavras. 2003;27(4):835-9.

Dixit G, Praveen A, Tripathi T, et al. Herbivore-responsive cotton phenolics and their impact on insect performance and biochemistry. J Asia-Pac Entomol. 2017;20(2):341-51. https://doi.org/10.1016/j.aspen.2017.02.002.

Dubois M, Gilles KA, Hamilton JK, et al. A colorimetric method for the determination of sugars. Nature. 1951;168(4265):167. https://doi.org/10.1038/1 $68167 \mathrm{a} 0$.

Government of Pakistan. Economic survey of Pakistan. Islamabad: Finance Division Economic Adviser's Wing; 2017-2018.

Irfan M, Mumtaz I, Raza ABM, et al. Effect of leaf morphology on the incidence of sucking insect pests in some cotton genotypes. Int J Cell Mol Biol. 2008;1(3): 285-91.

Khalil H, Bakar A, Raza M, et al. Effect of plant morphology on the incidence of sucking insect pests complex in few genotypes of cotton. J Saudi Soc Agric Sci. 2017;16:344-9. https://doi.org/10.1016/j.jssas.2015.11.003.

Khan MA, Akram W, Khan HAA, et al. Impact of Bt-cotton on whitefly, Bemisia tabaci (Genn.) population. Pak J Agric Sci. 2010;47(4):327-32.

Khan MT, Naeem M, Akram M. Studies on the varietal resistance of cotton against insect pest complex of cotton. Sarhad J Agri. 2003;19:93-6.

Nemade PW, Budhvat KP, Wadaskar PS. Population dynamics of sucking pests with relation to weather parameters in Bt cotton in Buldana district, Maharashtra, India. Int J Curr Microbiol App Sci. 2018;7(1):620-6.

Nizamani IA, Talpur MA, Khuhro RD, et al. Relative resistance of cotton cultivars to sucking complex. Pak J Appl Sci. 2002;2(6):686-9.

Oerke EC. Crop losses to pests. J Agric Sci. 2006;144:31-43. https://doi.org/10.101 7/S0021859605005708.

Pathan AK, Chohan S, Leghari MA, et al. Comparative resistance of different cotton genotypes against insect pest complex of cotton. Sarhad J Agric. 2007;23(1):141-3.

Perveen SS, Qaisrani TM, Amin S, et al. Biochemical basis of insect resistance in cotton. J Biol Sci. 2001;1(6):496-500. https://doi.org/10.3923/jbs.2001.496.500.

Razaq M, Suhail A, Aslam M, et al. Patterns of insecticides used on cotton before introduction of genetically modified cotton in southern Punjab, Pakistan. Pak J Zool. 2013:45:574-7.
Romano GB, Scheffler JA. Lowering seed gossypol content in glanded cotton (Gossypium hirsutum L.) lines. Plant Breed. 2008;127:619-24. https://doi.org/1 0.1111/j.1439-0523.2008.01545.x.

Saleem MJ, Hafeez F, Arshad M, et al. Population dynamics of sucking pests on transgenic Bt cotton in relation with abiotic factors and physiomorphological plant characters. J Entomol Zool Stud. 2018;6(6):163-6.

Singleton VL, Rossi JA. Colorimetry of total phenolics with phosphomolybdicphosphotungstic acid reagents. Am J Enol Viticult. 1965;16:144-58.

Sonalkar VU. Biochemicals in cotton hybrids and varieties and their correlation with sucking insect pests. Int J Curr Microbiol App Sci. 2020;9(1):1172-83.

Steel RGD, Torrie JH, Dickey DA. Principles and procedures of statistics: a biometrical approach. New York: McGraw Hill Book Co. Inc; 1997. p. 400-28.

War AR, Paulraj MG, Ahmad T, et al. Mechanisms of plant defense against insect herbivores. Plant Signal Behav. 2012;7:1306-20. https://doi.org/1 $0.4161 / p s b .21663$

Zia K, Ashfaq M, Arif MJ, et al. Effect of physico-morphic characters on population of whitefly, Bemisia tabaci in transgenic cotton. Pak J Agri Sci. 2011;48(1):63-
Ready to submit your research? Choose BMC and benefit from:

- fast, convenient online submission

- thorough peer review by experienced researchers in your field

- rapid publication on acceptance

- support for research data, including large and complex data types

- gold Open Access which fosters wider collaboration and increased citations

- maximum visibility for your research: over $100 \mathrm{M}$ website views per year

At $\mathrm{BMC}$, research is always in progress.

Learn more biomedcentral.com/submissions 